\title{
Frailty in elderly patients with chronic kidney disease under conservative treatment
}

\author{
Fragilidade em idosos com doença renal crônica em tratamento conservador
}

Aline de Sousa Meira ${ }^{1}$, Marcelo Aparecido Batista ${ }^{1}$, Roberta Maria de Pina Pereira ${ }^{1}$, Rosalina Aparecida Partezani Rodrigues $^{1}$, Jack Roberto Silva Fhon ${ }^{1}$, Luciana Kusumota ${ }^{1}$

Objective: to assess the frail level of the elderly with chronic kidney disease under conservative treatment. Methods: this is a cross-sectional and correlational study performed with 35 elderly. The frailty was assessed using the Edmonton Frail Scale instrument. A descriptive analysis and Spearman correlation coefficients were performed. Results: the frailty showed a minimal variation of 1 and maximum of 14, with a mean score 7.71 $( \pm 3.10)$. Women $(8.05 \pm 3.551)$ and illiterates $(9.57 \pm 2.637)$ showed a higher mean score of frail. By correlating the frail score, a moderate inverse correlation was found with years of study $(\mathrm{p}=0.033)$ and moderate positive correlation with some complications $(\mathrm{p}<0.05)$. Conclusion: the elderly with chronic kidney disease under conservative treatment showed some frailty degree, the highest levels were correlated with lower education and a higher number of clinical complications.

Descriptors: Aged; Renal Insufficiency, Chronic; Frail Elderly; Nursing.

Objetivo: avaliar o nível de fragilidade dosidosos com doença renal crônica em tratamento conservador. Métodos: estudo transversal e correlacional com 35 idosos. A fragilidade foi avaliada por meio do instrumento Edmonton Frail Scale. Realizou-se análise descritiva e os coeficientes de Correlação de Spearman. Resultados: a fragilidade apresentou variação de mínimo um e máximo 14 , com escore médio $7,71( \pm 3,10)$. As mulheres $(8,05 \pm 3,551)$ e os analfabetos $(9,57 \pm 2,637)$ apresentaram escore médio maior de fragilidade. Ao correlacionar a fragilidade, foi encontrada correlação inversa moderada com anos de estudo $(p=0,033)$ e correlação positiva moderada com número de complicações $(\mathrm{p}<0.05)$. Conclusão: os idosos com doença renal crônica em tratamento conservador apresentaram algum grau de fragilidade, os maiores níveis foram correlacionados com menor escolaridade e maior número de complicações clínicas.

Descritores: Idoso; Insuficiência Renal Crônica; Idoso Fragilizado; Enfermagem.

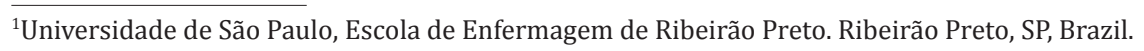

Corresponding author: Luciana Kusumota

Avenida dos Bandeirantes, 3900. Monte Alegre. CEP: 14040-902. Ribeirão Preto, SP, Brazil. E-mail: kusumota@eerp.usp.br 


\section{Introduction}

Life expectancy at birth in Brazil, in 2012, was 74.6 years old $^{(1)}$. With the increase in the elderly population, non-communicable chronic diseases have become more prevalent, among them, arterial hypertension and diabetes mellitus which is considered the main risk factors for developing Chronic Kidney Disease, considered a global public health problem and triggering complications such as cardiovascular problems and premature mortality ${ }^{(2)}$.

Chronic Kidney Disease is confirmed with glomerular filtration rate $<60 \mathrm{ml} / \mathrm{min} / 1.73 \mathrm{~m}^{2}$, for a period equal or less than three months, with implications for health and the diagnosis, is defined along with diagnostic tests such as renal function markers and imaging tests ${ }^{(3)}$.

With the aging natural process morphological changes occur, and there is a decrease in kidney function, as well as in other organs. Such changes may potentiate the impairment of renal function, already damaged by other factors, such as the presence of diabetes mellitus and systemic arterial hypertension ${ }^{(2)}$.

Every year there is an increase of $10.0 \%$ of patients with Chronic Kidney Disease, caused by increased blood pressure, which can be considered both cause and consequence of Chronic Kidney Disease. On the other hand, diabetes mellitus causes lesions in the microvasculature of the kidney, and about $30.0 \%$ of this patient with diabetes mellitus type 1 and 10 to $40.0 \%$ of type 2, develop Chronic Kidney Disease ${ }^{(3)}$.

The focus of treatment consisted of renal replacement therapy (dialysis and kidney transplantation) for the terminal stages of the disease; however, from the past decade, it has been shown through studies that the disease progression may be delayed in the early stages of Terminal Chronic Kidney Disease. The treatment called conservative, also known as pre or not dialysis, is the implementation of preventive measures such as nutritional intervention, strict control of blood pressure and blood glucose, aiming to delay the renal replacement therapy ${ }^{(2)}$.

According to the registration of the most recent estimates provided by the Brazilian Society of Nephrology in 2013, there were 100,397 patients treated with chronic dialysis. Concerning the age, $62.6 \%$ were between 19 and 64 years old, $26.7 \%$ between 65 and 80 years old and $4.7 \% 80$ years old or more ${ }^{(4)}$.

Chronic Kidney Disease accelerates metabolic changes, loss of functional reserve, increasing the aging process. Thus, the elderly tend to develop difficulties to perform their daily activities and become dependent ${ }^{(5)}$. In this context, frailty is considered a syndrome to be investigated in the elderly. However, there is a lack of consensus about the concept, and likewise, there are different ways to assess $i^{(6)}$.

A group of researchers of the University of Alberta in Canada believes that frailty is multidimensional, heterogeneous and unstable, in which there are three criteria that divide the frail elderly: the dependence in activities of daily living and instrumental life; vulnerability to environmental stressors; and acute and pathological states. Different from disability or aging process, the frailty is understood as a state of vulnerability, considering that biological, psychological, social and environmental aspects throughout life interfere with the determination of frailty ${ }^{(7)}$. Thus, they proposed the Edmonton Frail Scale to assess frailty in the elderly.

It should be noted that studies evaluating the frailty use different instruments but in a study in the interior of São Paulo with 240 elderly living at home, used the Edmonton Frail Scale and the authors identified among the elderly that $36.6 \%$ did not show frailty; $24.6 \%$ were apparently vulnerable; and $39.1 \%$ had different frailty levels, being $18.3 \%$ mild frailty; $11.3 \%$ moderate frailty and $9.6 \%$ severe frailty. It was also found that elderly women had a higher frailty level ${ }^{(8)}$.

Another study, also used the same instrument, with 60 participants users of a Replacement Renal Care Unit with Chronic Kidney Disease on hemodialysis 
treatment, and the authors found that $35.0 \%$ of the elderly did not show frailty, $26.7 \%$ showed vulnerable, $20.0 \%$ had mild frailty, $13.3 \%$ moderate frailty, and $5.0 \%$ severe frailty. Therefore, elderly frailty levels in hemodialysis were high $^{(9)}$.

The nurse should plan control and progression strategies of Chronic Kidney Disease and the identification of the frailty level can show the risk that the elderly are exposed ${ }^{(8)}$. Considering the elderly with Chronic Kidney Disease as a vulnerable group with changes resulting from the aging process, the involvement of based diseases and Chronic Kidney Disease, it is relevant to assess the frailty levels of the elderly. Through this assessment, the nurse can recognize the changes, plan and implement individualized health actions to achieve the needs of the elderly. The aim of the study was to evaluate the frailty level of the elderly with Chronic Kidney Disease under conservative treatment.

\section{Methods}

This is a cross-sectional and correlational study. This study is part of the research project entitled "Frailty and quality of life of elderly with Chronic Kidney Disease." The study was conducted in a uremia outpatient clinic of a public hospital in São Paulo. For the sample, the participant must meet the following inclusion criteria: be 60 years old or older, with a diagnosis of Chronic Kidney Disease under conservative treatment and not be hospitalized for any complications related or unrelated to the diagnosis of the disease.

Data collection took place from December 2014 to March 2015; data were collected through interviews with the elderly in outpatient at doctor's return day, so the sample was for convenience, totaling 35 elderly. The interviews lasted about forty minutes.

An appropriate characterization instrument was used, which was shown as valid in other researchers with patients with Chronic Kidney Disease $^{(10)}$. This instrument contains the socio- demographic and economic data (age in years; male and female gender, marital status, education, type of income) and clinical (treatment time, complications related to the disease, comorbidity).

The frailty was assessed through the application of the instrument Edmonton Frail Scale - in elderly constructed by a Canadian group, culturally adapted and validated to Brazil in 2009. This instrument evaluates nine domains: cognition, general health status, functional independence, social support, drug use, nutrition, humor, continence and functional performance. Regarding the results, the score ranges from 0 to 17 , where 0 corresponding to absence and 17 corresponding to the most severe frailty level. This scale is considered reliable, and easy and quick application $^{(6-7)}$.

For the analysis, the data were double entered into an Excel ${ }^{\circledR}$ spreadsheet, validated and checked. After that, the Statistical Package of Social 21,0, was used, and descriptive analysis and univariate and bivariate frequency, contingency tables, position measurements (mean) and variability (minimum, maximum, and standard deviation) were carried out. For the analysis of the correlation between frailty and socio-demographic and clinical variables, the Spearman Correlation was used with a statistical significance of $\mathrm{p}<0.05$.

The study complied with the formal requirements contained in the national and international standards of regulatory research involving human beings.

\section{Results}

As for socio-demographic characteristics, from the 35 elderly, 16 (45.7\%) were male and 19 (54.3\%) female. The minimum age was 60 years old and the maximum 87 years old, having an average of 68.26 years. As for marital status, 20 (57.1\%) lived with their spouses or partners.

Regarding social profile, the minimum time study was three months, maximum 14 years and 
the mean 3.94 years of study. Concerning the source of income, it is emphasized that from the 35 elderly, $27(77.1 \%)$ were retired (as) and three (8.6\%) were working.

Regarding the clinical characterization of Chronic Kidney Disease and treatment, conservative treatment time averaged 4.62 years, minimum six months and a maximum of 21 years.

As the complications associated with the disease, the most self-reported were high pressure $(27 ; 77.1 \%)$, followed by cramps $(20 ; 57.1)$, anemia (19; 54.3\%), loss weight (19; 54.3\%), pain (18; 51.4\%), among others (Table 1). The average number of complications in elderly was 5.6.

Table 1 - Clinical characterization of 35 elderly with Chronic Kidney Disease under conservative treatment

\begin{tabular}{lc}
\hline Variables & $\mathbf{n}(\%)$ \\
\hline Complications & $27(77.1)$ \\
High Pressure & $20(57.1)$ \\
Cramping & $19(54.3)$ \\
Anemia & $19(54.3)$ \\
Weight loss & $18(51.4)$ \\
Pain & $17(48.6)$ \\
Weakness & $17(48.6)$ \\
Weight gain & $15(42.9)$ \\
Constipation & $12(34.3)$ \\
Heart Arrhythmia & $10(28.6)$ \\
Headache & $10(28.6)$ \\
Itch & $8(22.9)$ \\
Recurrent infections & $4(11.4)$ \\
Arterial hypertension &
\end{tabular}

Concerning morbidities, the most selfreported were the visual deficit $(23 ; 65.7 \%)$, arterial hypertension (22; 62.9\%), Diabetes mellitus (18; $51.4 \%)$, cataract $(16 ; 45.7 \%)$, myocardial infarction
(11; 31.4\%), among others (Table 2). The average number of self-reported comorbidities in the elderly was 3.7.

Table 2 - Self-reported comorbidities by 35 elderly with Chronic Kidney Disease under conservative treatment

\begin{tabular}{lc}
\hline Variables & n (\%) \\
\hline Visual Deficit & $23(65.7)$ \\
Systemic arterial hypertension & $22(62.9)$ \\
Diabetes mellitus & $18(51.4)$ \\
Cataract & $16(45.7)$ \\
Acute myocardial infarction & $11(31.4)$ \\
Varicose veins & $9(25.7)$ \\
Hearing deficit & $7(20.0)$ \\
Cerebrovascular disease & $5(14.3)$ \\
Osteopathy & $5(13.3)$ \\
Malignant neoplasm & $4(11.4)$ \\
Cardiac insufficiency & $3(8.6)$ \\
Benign neoplasm & $1(2.9)$ \\
Malnutrition & $1(2.9)$ \\
Asthma & $1(2.9)$ \\
Tendonitis & $1(2.9)$ \\
Labyrinthitis & $1(2.9)$ \\
Thrombosis & $1(2.9)$ \\
\hline
\end{tabular}

In the frailty evaluation, there was a minimum score of 1 and maximum of 14 , with a mean of 7.71 and standard deviation of 3.10 .

Regarding the distribution of the frailty results with the variables, gender, education, retirement, systemic arterial hypertension and diabetes mellitus, it was observed that women $(8.05 \pm 3.551)$, illiterates $(9.57 \pm 2.637)$, elderly who were not retired $(8.00 \pm 2.944)$, non-hypertensive $(8.00 \pm 2.944)$ and diabetics (8.06 \pm 3.038$)$ had higher mean score of frailty (Table 3). 
Table 3 - Average comparison of frailty with the variables: gender, education, retirement, systemic arterial hypertension and diabetes mellitus of elderly with Chronic Kidney Disease under conservative treatment

\begin{tabular}{lcc}
\hline Variables & n (\%) & $\begin{array}{c}\text { Average } \pm \text { Standard } \\
\text { deviation }\end{array}$ \\
\hline Gender & $16(45.7)$ & $7.31 \pm 2.522$ \\
$\quad$ Male & $19(54.3)$ & $8.05 \pm 3.551$ \\
$\quad$ Female & $28(80.0)$ & $7.24 \pm 3.075$ \\
Education & $7(20.0)$ & $9.57 \pm 2.637$ \\
$\quad$ Can read/write & & \\
$\quad$ Illiterate & $27(77.1)$ & $7.63 \pm 3.318$ \\
Retirement & $8(22.9)$ & $8.00 \pm 2.390$ \\
$\quad$ Yes & & \\
$\quad$ No & $22(62.9)$ & $7.55 \pm 3.247$ \\
Systemic arterial hypertension & $13(33.1)$ & $8.00 \pm 2.944$ \\
$\quad$ Yes & & \\
$\quad$ No & $18(51.4)$ & $8.06 \pm 3.038$ \\
Diabetes mellitus & $17(48.6)$ & $7.35 \pm 3.220$ \\
$\quad$ Yes & & \\
No & & \\
\hline
\end{tabular}

By correlating the frailty with years of study, the results showed a moderate inverse correlation with statistical significance $(\mathrm{p}=0.033)$, indicating that the higher the years of study of the elderly, the lesser were the frailty levels. The number of complications showed moderate positive correlation with statistical significance $(\mathrm{p}<0.05)$ with the frailty, suggesting that as the number of complications increase in the elderly, also increases the frailty level (Table 4).

Table 4 - Correlation between frail score and demographic and clinical variables of patients with Chronic Kidney Disease under conservative treatment

\begin{tabular}{lcc}
\hline Variables & $\begin{array}{c}\text { Spearman's correlation } \\
\text { coefficient }\end{array}$ & p-value \\
\hline Age & -0.059 & 0.738 \\
Years of study & -0.378 & $0.033^{*}$ \\
Treatment time & -0.087 & 0.619 \\
Memory & 0.313 & 0.067 \\
Number of complications & 0.666 & $0.000^{*}$ \\
Number of comorbidities & 0.216 & 0.212 \\
\hline *Statistical significance for $\mathrm{p}<0.05$ & &
\end{tabular}

\section{Discussion}

The frailty theme lacks investments and scientific production ${ }^{(11)}$, mainly in the analysis of relationships with specific population characteristics, such as the elderly with Chronic Kidney Disease under conservative treatment. This study could characterize the frailty and demonstrate some correlations with independent variables such as education and clinical complications, corroborating with scientific findings from studies of other elderly populations ${ }^{(8-9,12)}$. The small number of elderly participants of the research was a study limitation that restricted the analyses, especially the deepening of relations between frailty and aspects of senescence and senility of this elderly.

Physical frailty is common among adults and elderly with Chronic Kidney Disease, including those under conservative treatment, and there is an approximately double probability of patients with Chronic Kidney Disease being fragile when compared to people with normal renal function ${ }^{(13)}$. The mean score of elderly's frailty in this study $(7.71 \pm 3.10)$ corroborates this statement, but it is worth mentioning the multidimensional nature of the reference used in this study, considering that cognition, mood, and social support are also important aspects determining the frailty ${ }^{(7)}$.

Some socio-demographic and clinical characteristics have been associated with higher frailty levels ${ }^{(8-14)}$. Regarding education, on this study, the greatest frailty levels are correlated with lower years of study of the elderly. The low level of education is associated with cognitive decline and results in the lack of benefits and social opportunities for the elderly, triggering functional restrictions and increasing the risk of frailty ${ }^{(15-16)}$. Therefore, the social aspects can mean risk factors for frailty(15).

Regarding clinical characteristics, the largest number of clinical complications of the elderly is correlated with higher frailty levels. The frail patients with Chronic Kidney Disease is associated among other variables with the presence of comorbidities, 
such as anemia, stroke and cardiovascular disease ${ }^{(12)}$. Anemia, a common complication of Chronic Kidney Disease, limited physical activity and is associated with weakness, fatigue, and exhaustion. Also, other symptoms are also common such as the cramp, pain, pruritus, among others, and there is most often, an overlap of several of these complications in the same elderly with chronic kidney disease $\mathrm{e}^{(2-3)}$.

The high number of complications enhances vulnerability; thus, the functional decline, compromise the homeostasis and the elderly capacity, making them fragile ${ }^{(17)}$. The clinical manifestations tend to worsen in the advanced stages of Chronic Kidney Disease ${ }^{(2)}$ and to consider that care has been focused on maintaining renal function in establishing the diagnosis of chronic kidney disease, the treatment of its complications and comorbidities and adequacy of dialysis ${ }^{(13)}$, the frailty comes as a multidimensional construct to be addressed and included for optimization of care for elderly with Chronic Kidney Disease.

The frailty can be considered as a new geriatric syndrome $^{(18)}$, but is not yet clarified the association of decline in glomerular filtration rate and an increase of creatinine to determine malnutrition, frailty, and sarcopenia in the elderly increasing mortality ${ }^{(19)}$.

To identify and characterize the frailty and the associated aspects is relevant to the health practice. The nurse has proposed a comprehensive and multidisciplinary care for the frail elderly ${ }^{(20)}$. On the other hand, as important to deal with, it is also necessary to address aspects for the prevention of frailty in which the healthcare professional performing the global assessment of the elderly, can identify risk factors for frail and plan actions to prevent and/or control the progression to more severe levels.

It is also worth mentioning in this study, the need for new studies evaluating the frailty of Brazilian elderly with Chronic Kidney Disease and performing conservative treatment, and allow making comparisons, as well as address the applicability of prevention methods and treatment of frailty on this elderly.

\section{Conclusion}

Given the average score of the Edmonton Frail Scale (7.71), found in elderly with Chronic Kidney Disease under conservative treatment, it can be seen that the study participants had some frailty degree. Regarding the correlational analysis, the elderly showed greater frailty levels correlated with lower education and a higher number of clinical complications.

\section{Collaborations}

Meira AS, Batista MA, Pereira RMP and Kusumota L contributed to the project design, analysis and interpretation of data, article writing and critical review of relevant intellectual content. Rodrigues RAP and Fhon JRS contributed to final approval of the version to be published.

\section{References}

1. Instituto Brasileiro de Geografia e Estatística. Expectativa de vida [Internet]. 2013 [citado 2014 dez 10]. Disponível em: http://teen.ibge.gov.br/ noticias-teen/7827-expectativa-de-vida.html

2. Bastos MG, Kirsztajn GM. Doença Renal Crônica: importância do diagnóstico precoce, encaminhamento imediato e abordagem interdisciplinar estruturada para melhora do desfecho em pacientes ainda não submetidos à diálise. J Bras Nefrol. 2011; 33(1):93-8.

3. Kirsztajn GM, Filho NS, Draibe AS, Netto MVP, Thomé FS, Souza E, et al. Leitura rápida do KDIGO 2012: Diretrizes para avaliação e manuseio da Doença Renal Crônica na prática clínica. J Bras Nefrol. 2014; 36(1):63-73.

4. Sesso RC, Lopes AA, Thomé FS, Lugon JR, Santos DR. Inquérito Brasileiro de Diálise Crônica 2013 Análise das tendências entre 2011 e 2013. J Bras Nefrol. 2014; 36(4):476-81. 
5. Kim JC, Kalantar-Zadeh K, Kopple JD. Frailty and protein-energy wasting in elderly patients with end stage kidney disease. J Am Soc Nephrol. 2013; 24(3):337-51.

6. Fabricio-Whebe SCC, Cruz IR, Hass VJ, Diniz MA, Dantas RAS, Rodrigues RAP. Reproducibility of the Brazilian version of the Edmonton Frail Scale for elderly living in the community. Rev Latino-Am Enfermagem. 2013; 21(6):1330-6.

7. Rolfson DB, Majumdar SR, Tsuyuki RT, Tahir A, Rockwood K. Validity and reability of the Edmonton Frail Scale. Oxford J Age Agein. 2006; 35(5):526-9.

8. Fhon JRS, Diniz MA, Leonardo KC, Kusumota L, Haas VJ, Rodrigues RAP. Frailty syndrome related to disability in the elderly. Acta Paul Enferm. 2012; 25(4):589-94.

9. Orlandi FS, Gesualdo, GD. Assessment of the frailty level of elderly people with chronic kidney disease undergoing hemodialysis. Acta Paul Enferm. 2014; 27(1):29-34.

10. Kusumoto L, Marques S, Haas VJ, Rodrigues RAP. Adults and elderly on hemodialysis evaluation of health related quality of life. Acta Paul Enferm. 2008; 21(spe):152-9.

11. Linck CL, Crossetti MGO. Fragilidade no Idoso: 0 que vem sendo produzido pela enfermagem. Rev Gaúcha Enferm. 2011; 32(2):385-93.

12. Storti LB, Fabrício-Whebe SCC, Kusumota L, Rodrigues RAP, Marques S. Frailty of elderly patients admitted to the medical clinic of an emergency unit at a general tertiary hospital. Texto Contexto Enferm. 2013; 22(2):452-9.
13. Mansur HN, Damasceno VO, Bastos MG. Prevalência da fragilidade entre os pacientes com doença renal crônica em tratamento conservador e em diálise. J Bras Nefrol. 2012; 34(2):153-60.

14. Reese PP, Cappola AR, Shults J, Townsend RR, Gadegbeku CA, Anderson Ch, et al. Physical performance and frailty in chronic kidney disease. Am J Nephrol. 2013; 38(4):307-15.

15. Neri AL, Yassuda MS, Araújo LF, Eulálio MC, Cabral BE, Catunda SME, et al. Metodologia e perfil sociodemográfico, cognitivo e de fragilidade de idosos comunitários de sete cidades brasileiras: Estudo FIBRA. Cad Saúde Pública. 2013; 29(4):778-92.

16. Szanton SL, Seplaki CL, Thorpe RJ, Allen JK, Fried LP. Socioeconomic status is associated with frailty: the Women's Health and Aging Studies. J Epidemiol Community Health. 2010; 64(1):63-7.

17. Lana LD, Schneider RH. Síndrome de fragilidade no idoso: uma revisão narrativa. Rev Bras Geriatr Gerontol. 2014; 17(3):673-80.

18. Abdfelhafiz AH, Ahmed S, Flint K, El Nahas M. Is chronic kidney disease in older people a geriatric giant? Aging Health. 2011; 7(5):449-62.

19. Peters R, Beckett N, Poulter R, Burch L, Narkiewwicz K, Fagard R, et al. Kidney function in the very elderly with hypertension: data from the hypertension in the very elderly (HYVET) trial. Age Ageing. 2013; 42(2):253-8.

20. Linck CL, Crossetti MGO. Fragilidade no Idoso: 0 que vem sendo produzido pela enfermagem. Rev Gaúcha Enferm. 2011; 32(2):385-93. 